\title{
A new Tenuiphantes Saaristo et Tanasevitch, 1996 from the Caucasus, Russia (Arachnida: Aranei: Micronetinae)
}

\author{
Новый вид рода Tenuiphantes Saaristo et Tanasevitch, 1996 \\ с Кавказа, Россия (Arachnida: Aranei: Micronetinae)
}

\author{
Andrei V. Tanasevitch \\ A.B. Танасевич \\ Centre for Forest Ecology and Production, Russian Academy of Sciences, Profsoyuznaya Str. 84/32, Moscow 117997, Russia. E-mail: and- \\ tan@mail.ru. \\ Центр по проблемам экологии и продуктивности лесов РАН, Профсоюзная ул. 84/32, Москва 117997, Россия.
}

KEY WORDS: Spiders, Linyphiidae, new species, Caucasus, Russia.

КЛЮЧЕВЫЕ СЛОВА: Пауки, Linyphiidae, новый вид, Кавказ, Россия.

ABSTRACT. Tenuiphantes teberdaensis sp.n. is described from the Caucasus, Russia, differing from congeners by the peculiar shape of the protruding lamella characteristica in the male, as well as by some details of scape structure in the female.

РЕЗЮМЕ. С Кавказа (Россия) описан новый вид Tenuiphantes teberdaensis sp.n., отличающийся от других видов рода сильно выступающей ламеллой пальпы самца, а также деталями строения скапуса эпигины самки.

\section{Introduction}

New linyphiid spider collections from the Caucasus still reveal new species. Thus, a new species of the genus Tenuiphantes Saaristo et Tanasevitch, 1996 has emerged as the result of a recent survey of the litterdwelling spiders from the mountain forests of the Teberda Nature Reserve. The present paper is devoted to its description.

\section{Material and methods}

This paper is based on the spider material collected by F. Martynovchenko in 2008 from the Teberda Nature Reserve, Karachay-Cherkessia Republic, Caucasus, Russia.

The holotype and most of the paratypes are deposited in the Zoological Museum of the Moscow State University, Moscow, Russia (by default); some duplicates are in the collection of the Muséum d'Histoire Naturelle, Geneva, Switzerland.

In the descriptions, chaetotaxy is given as follows: e.g., Ti I: 2-1-1-2(1), which means that the tibia I has two dorsal, one pro- and one retrolateral spine, and two or one ventral spine (the apical spines are disregarded). The sequence of leg segment measurements is as follows: Femur + patella + tibia + metatarsus + tarsus. All measurements are given in $\mathrm{mm}$. Scale lines in the figures are $0.1 \mathrm{~mm}$ unless indicated otherwise.

The terminology of the genitalic structures follows that after Saaristo \& Tanasevitch [1996].

Abbreviations used in the text and figures: $\mathrm{Ca}-$ carina, EP - embolus proper, Fe — femur, MHNG Muséum d'Histoire Naturelle, Geneva, MPS - middle part of scape, Mt - metatarsus, PMP - posterior median plate, $\mathrm{P}$ - proscape, $\mathrm{Th}-$ thumb, Ti - tibia, $\mathrm{Tm}$ I - position of trichobothrium on tibia I.

\section{Tenuiphantes teberdaensis sp.n.} Figs 1-11.

MATERIAL: Holotype $\sigma^{\top}$, Russia, Caucasus, Karachay-

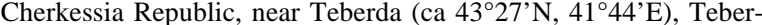
da Nature Reserve, Mt Malaya Khatipara, $1800 \mathrm{~m}$ a.s.1., elfin Betula forest, sweeping, 4.IX.2008, leg. F. Martynovchenko. Paratypes: 1 , same locality, together with holotype, 4.IX.2008, leg. F. Martynovchenko; $2 \sigma^{\top} \sigma^{\top}, 1800 \mathrm{~m}$ a.s.1., same locality, elfin Betula forest, sweeping, 23.VIII.2008, leg. F. Martynovchenko; 1 $\sigma^{7}, 1$ (MHNG), same locality, Fagus forest, $1350 \mathrm{~m}$ a.s.1., hand collecting, 6.IX.2008, leg. F. Martynovchenko; $1 \sigma^{\gamma}$, same locality, Betula forest with Calamagrostis sp., $2000 \mathrm{~m}$ a.s.1., pitfall trapping, 29.VIII.-15.IX.2008, leg. F. Martynovchenko.

DIAGNOSIS: The new species differs well by the peculiar shape of the lamella characteristica, as well as scape structure.

ETYMOLOGY. The species name is derived from the locality where the new species was found; adjective.

DESCRIPTION. Male. Total length, 2.90. Carapace 1.35 long, 1.10 wide, brown, with a grey median spot and an infuscate margin (Fig. 9). Chelicerae 0.65 long, unmodified. Legs pale brown, without median bands. Leg I -7.80 long $(1.90+0.40+2.05+2.30+$ 1.15), IV - ?; Fe IV 1.85 long. Chaetotaxy. Fe I: 0-1- 


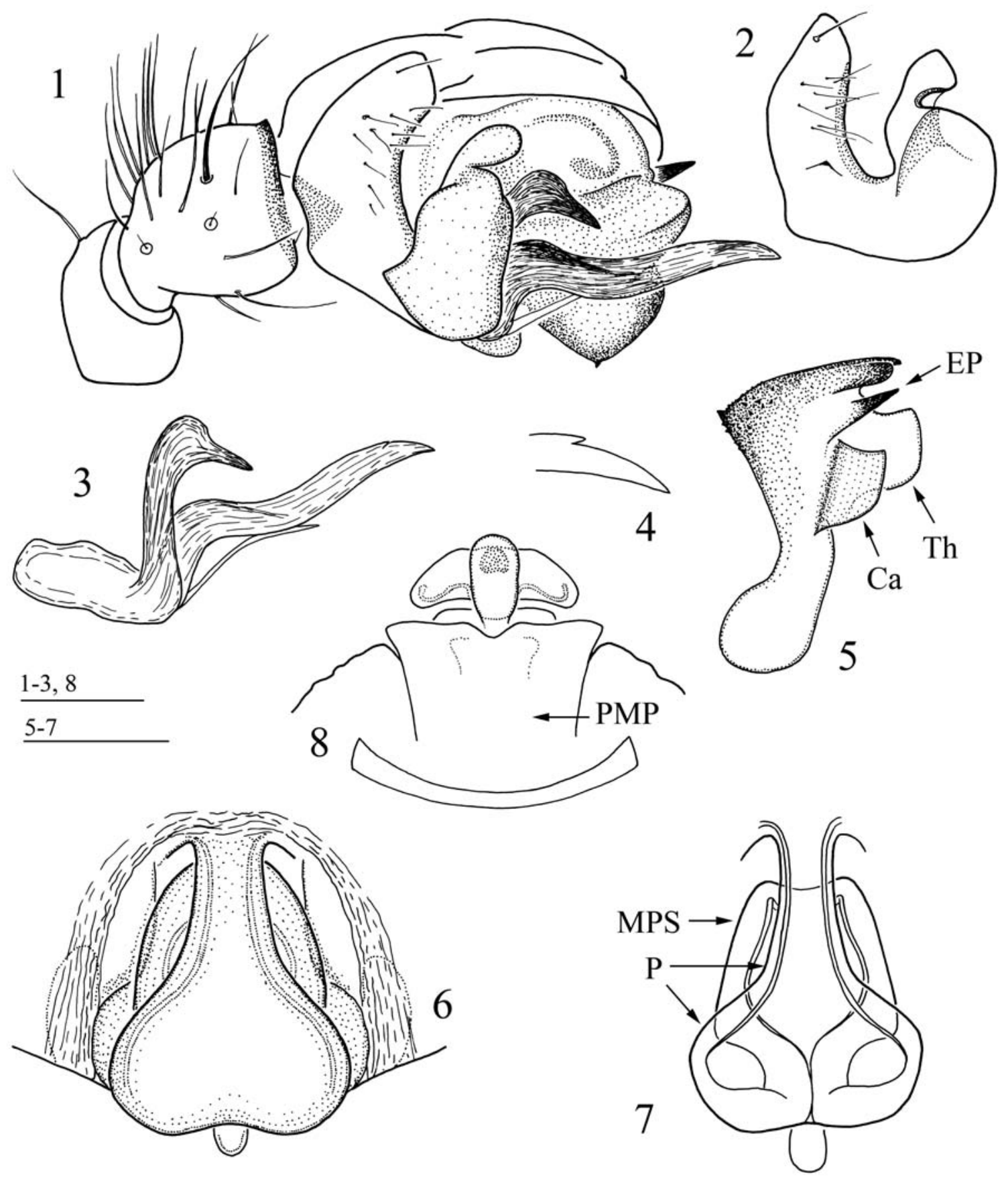

Figs 1-8. Tenuiphantes teberdaensis sp.n.: 1 - right palp; 2 - paracymbium; 3 - lamella characteristica; 4 - apex of lamella characteristica; 5 - embolus; $6 \& 8$ - epigyne, ventral and dorsal views, respectively; 7 - scape. Abbreviations: $\mathrm{Ca}-\mathrm{carina}$, $\mathrm{EP}-$ embolus proper, MPS - middle part of scape, $\mathrm{P}$ - proscape, PMP — posterior median plate, Th - thumb.

Pис. 1-8. Tenuiphantes teberdaensis sp.n.: 1 - правая пальпа; 2 - парацимбиум; 3 - lamella characteristica; 4 - апекс lamella characteristica; 5 - эмболюс; 6, 8 - эпигина (соответственно вид снизу и сверху); 7 - скапус.

0-0, Fe II-IV: 0-0-0-0; Ti I-III: 2-1-1-0, IV: ?; Mt I: 11-1-0, II-IV: ?; Tm I - 0.17. Palp (Figs 1-5): Cymbium without posterodorsal outgrowth. Paracymbium large, proximal part with a small tooth. Lamella characteristica with two branches: one small and S-shaped, the other one like a long, almost straight stripe sharpened distally. Embolus with both lateral extension (= thumb) and carina well-expressed. Embolus proper spear-shaped. Abdomen 1.40 long, 1.00 wide, dorsal pattern as in Fig. 9. 


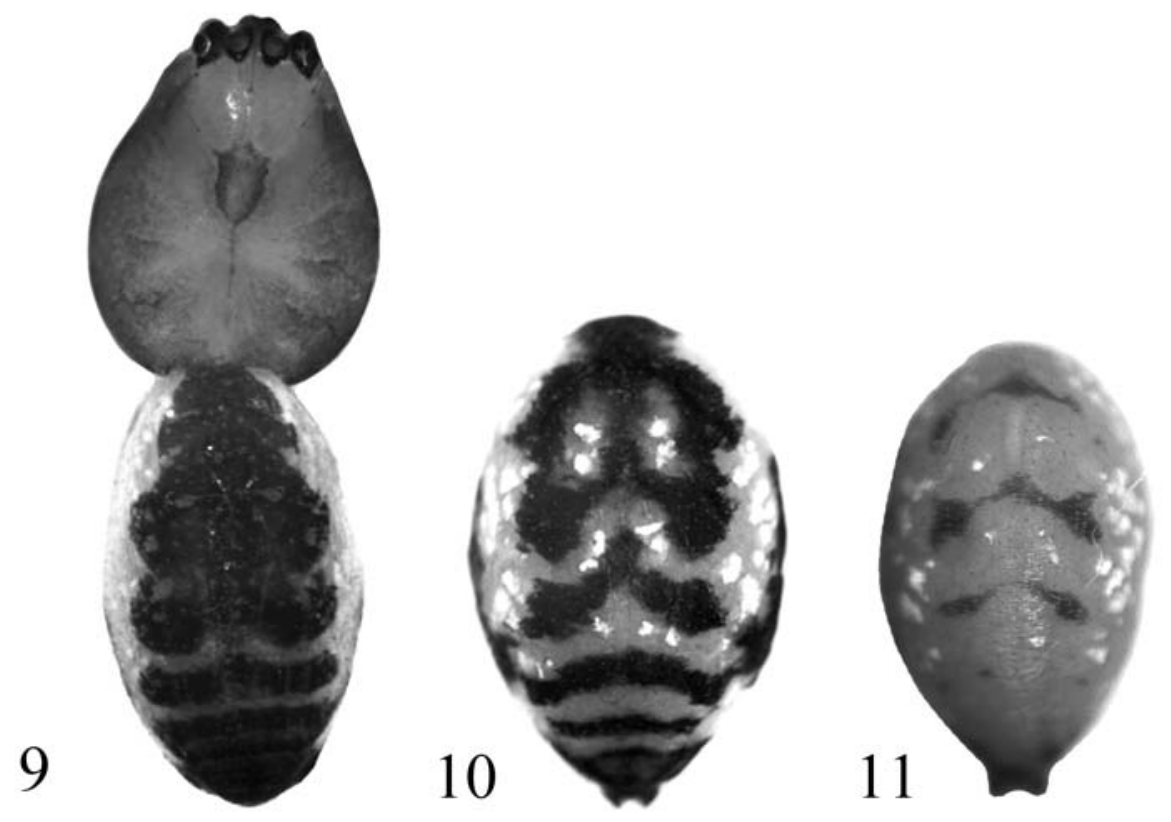

Figs 9-11. Tenuiphantes teberdaensis sp.n.: 9 - male body (dorsal view); 10 \& 11- female abdomen (dorsal view). Рис. 9-11. Tenuiphantes teberdaensis sp.n.: 9 - самец (вид сверху); 10, 11 - брюшко самки (вид сверху).

Female. Total length, 3.50. Carapace 1.35 long, 1.00 wide, brown, without median spot. Chelicerae 0.60 long. Leg I -6.45 long $(1.60+0.40+1.85+$ $1.60+1.00)$, IV -5.50 long $(1.50+0.35+1.40+$ $1.45+0.80)$. Chaetotaxy. Fe I: 0-1-0-0, Fe II-IV: 0-00-0; Ti I-IV: 2-1-1-0; Mt I-III: 1-1-1-0, IV: ?; Tm I 0.19. Abdomen as in Figs $10 \& 11,2.25$ long, 1.50 wide. Epigyne (Figs 6-8): Proscape pyriform, with a long and narrow proximal part. Middle part of scape well-visible from behind on either side of proximal part. Posterior median plate wide, with a small hollow in the middle. Leg coloration and chaetotaxy as in male.

TAXONOMIC REMARKS. The male of the new species differs well from the other allied Caucasian congeners, i.e., T. aequalis (Tanasevitch, 1987), T. contortus (Tanasevitch, 1986), and T. morosus (Tanasevitch, 1987), by the absence of teeth in the proximal part of the embolus and by the shape of the lamella characteristica. The epigyne of $T$. teberdaensis sp.n. is similar to that of T. aequalis (Tanasevitch, 1987), but differs by the longer proximal part of the proscape, as well as by the shape of the middle part of the scape, being abruptly narrowed down in $T$. aequalis, versus smoothly broadened in T. teberdaensis sp.n.

ACKNOWLEDGEMENTS. I am most grateful to Fedor Martynovchenko (Moscow, Russia), whose material served as the basis of the present paper, as well as to Sergei Golovatch (Moscow, Russia) for checking the English of a draft. This study was supported in part by the Russian Foundation for Basic Research, Projects \# 09-04-01365-a, and \# 08-0492230-a.

\section{References}

Saaristo M.I., Tanasevitch A.V. 1996. Redelimitation of the subfamily Micronetinae Hull, 1920 and the genus Lepthyphantes Menge, 1866 with descriptions of some new genera // Ber. nat.-med. Verein Innsbruck. Bd.83. S.163-186. 